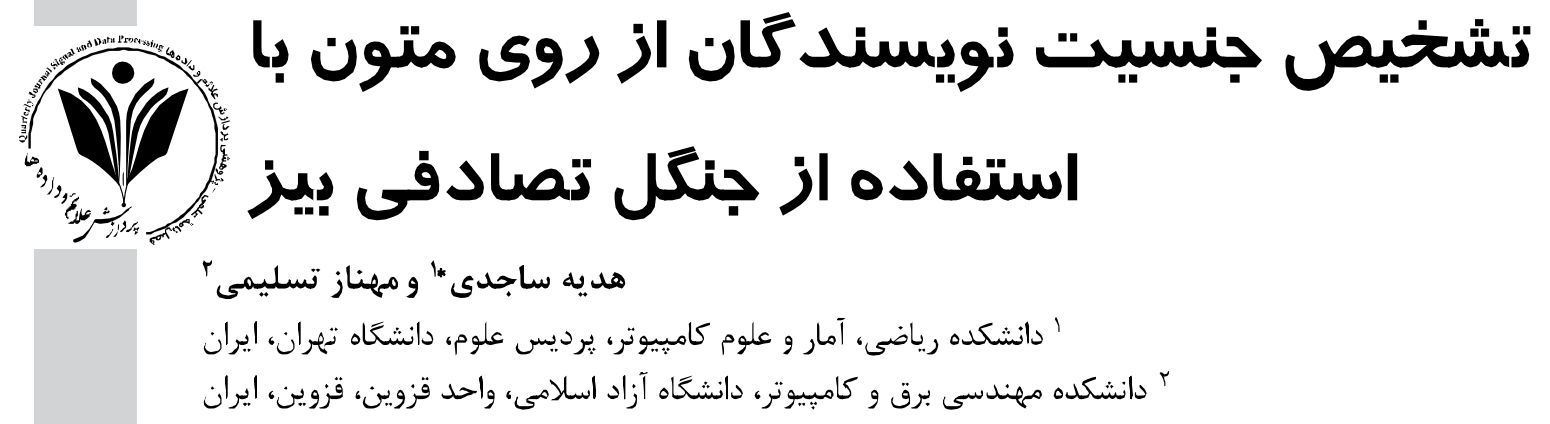

جكکبه

امروزه استفاده زياد كاربران از محيطهاى مجازى و ارتباط آنها از طريق شبكههاى اجتماعى مانند فيسبوكى و توييتر لزوم بررسى مطالب موجود

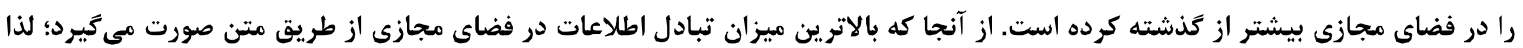

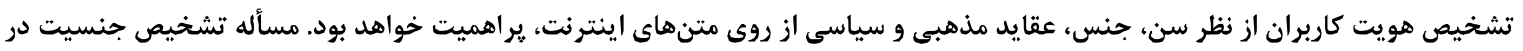

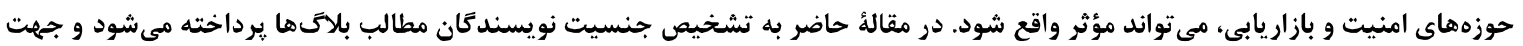

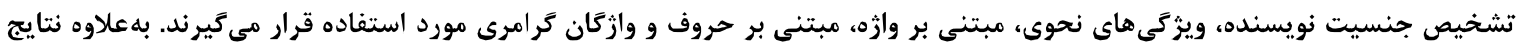

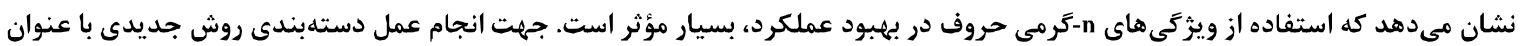

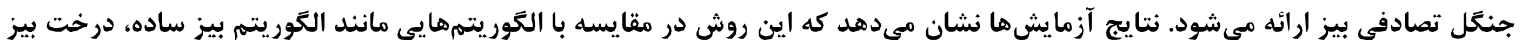

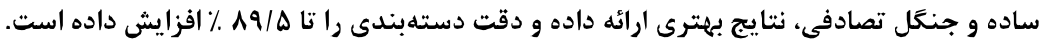
وازًَان كليدى: تشخيص جنسيت نويسنده، جنگل تصادفى، درخت بيز ساده، متن كاوى، دستهبندى.

\title{
Author gender identification from text using Bayesian Random Forest
}

\author{
Hedieh Sajedi*1 \& Mahnaz Taslimi ${ }^{2}$ \\ ${ }^{1}$ School of Mathematics, Statistics and Computer Science, College of Science, University of \\ Tehran, Iran \\ ${ }^{2}$ Computer and Electrical Engineering, Azad Islamic University, Qazvin Branch, Qazvin, Iran
}

\begin{abstract}
Nowadays high usage of users from virtual environments and their connection via social networks like Facebook, Instagram, and Twitter shows the necessity of finding out shared subjects in this environment more than before. There are several applications that benefit from reliable methods for inferring age and gender of users in social media. Such applications exist across a wide area of ficlds, from personalized advertising to law enforcement of reputation management. Text posts represent a large portion of user generated content, and contain information which can be relevant to discovering undisclosed user attributes, or investigating the honesty of self-reported age and gender. Because the highest rate of information exchanges is in text format, author identification from the aspects like age, gender, political and religious opinions from these contents will seem more considerable. Gender identification that could be useful in security and marketing, also answers the following question: given a short text document, can we identify if the author is a male or a female? This question is motivated by recent events where people faked their gender on the Internet. In this paper, author gender identification in blog's data is investigated. In this regard, four groups of features include syntactic features, word-based features, character-based features, and function words are employed. In addition,
\end{abstract}

* Corresponding author * نويسنده عهلهدار مكاتبات 
character n-gram features is used for improving the accuracy of classification. For evaluation of the proposed method, 3212 texts were collected from Technorati.com and blogger.com. Experimental results demonstrate that these types of features are practical. furthermore, a new classification method called "Bayesian Random Forest" is introduced. Each tree in Bayesian Random Forest is a Bayes tree. The results of experiment-show that this method attains noticeable results in comparison with other classification algorithms such as Naïe Bayes, Naïve Bayes Tree, and Random Forest and it increases accuracy of gender identification to $89.5 \%$.

Keywords: Author gender identification, Random Forest, NBTree, Text mining, Classification.

فضاى عمومى و همجنين سياسى شامل دولت و تجارت است

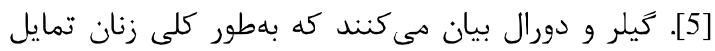

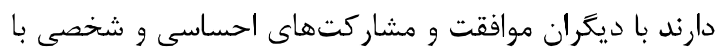

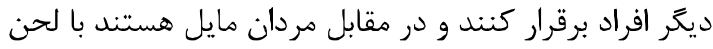

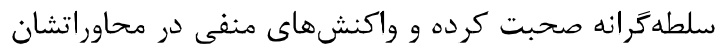
به كار برند [6]. از طرفى استفاده از يافتههاى علهم روانشناسى

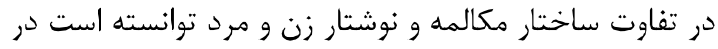

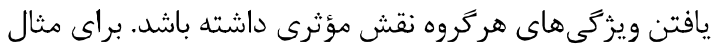

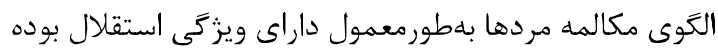
و تأكيد بر قدرت سلسلهمراتبى از بالا به هايين دارد؛ بنابراين

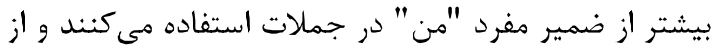

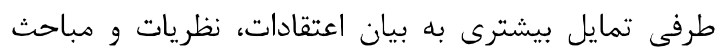
سياسى دارند و در مقابل زنان به ميزان زيادى درباره

احساسات، نخرانىها و روابط خانوادگى بحث مى كنند [1] شناخت تفاوتهاى جنسيتى از روى متن و اهميت آنها بيشتر در دو حيطه امنيت و بازاريابى مورد توجه قرار مى كيرد.

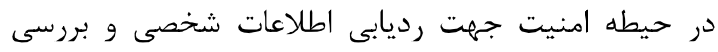
تمايلات هر جنس، بررسى عقايد اصلى هرگروه و شناخت

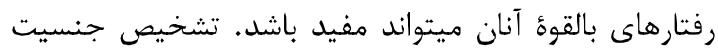

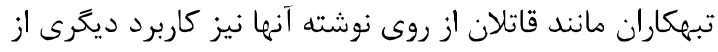

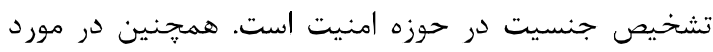

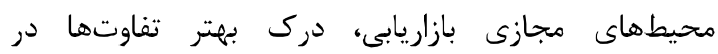

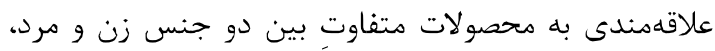

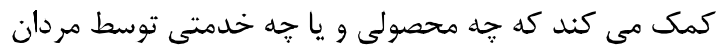

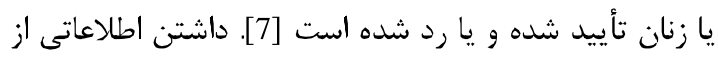

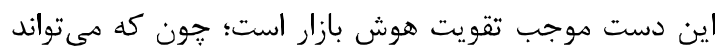
باعث هدفمندشدن تبليغات و توسعه محصولات شود.

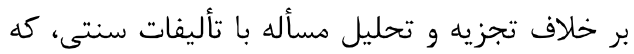

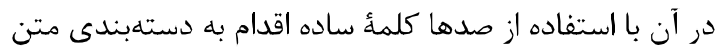
مىشد، در متون اينترنتى با جالشهايى از جمله استفاده از إندان

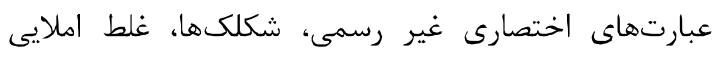

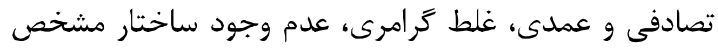

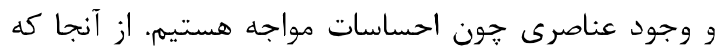
اين متون هيج شباهتى به نوشته وناى رسمى مانند كتاب، آثار

\section{do - 1}

با وجود اينكه فناورىهاى متفاوت ارتباطى در ساليان اخير

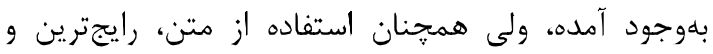

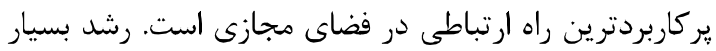

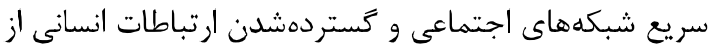
طريق دنياى مجازى، سبب بدوجودآمدن مقدار زيادى داده

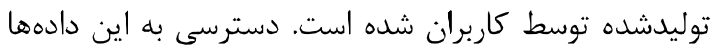

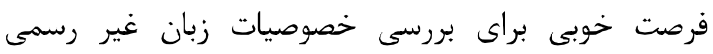

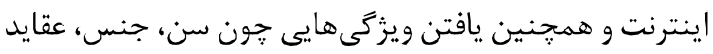
مذهبى و سياسى گرووهاى مختلف مردم فراهم آورده است

حمنامبودن، يك ويثزى مهلم در ارتباطات اينترنتى

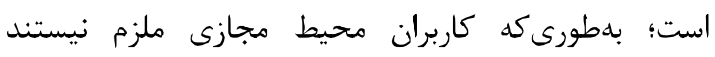
اطلاعات شخصى خود را بهطور صحيح بيان كنند؛ لذا لزوم يافتن روشهاى كارامد جهت تشخيص هويت كاربران اينترنت

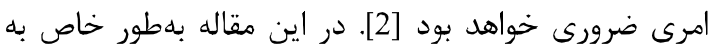

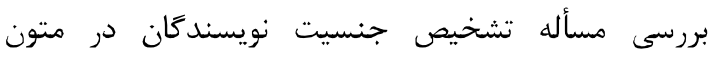
نوشتهشده در بلاكَها يرداخته شده است.

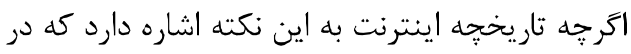

كَشته اينترنت بهعنوان يك محيط مجازى مختص به مردان

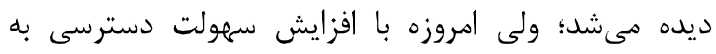

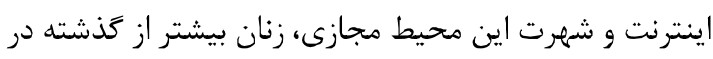

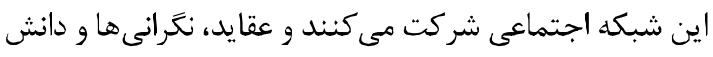

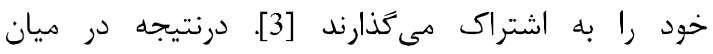

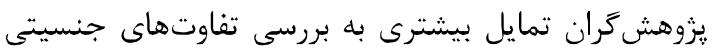

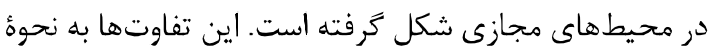

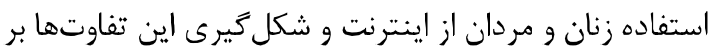
اساس تمايلات و روحياتشان اشاره دارد [4]. بهعنوان مثال

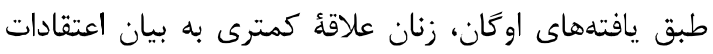
سياسى داشته و كمتر از حالت سلطه جويانه در مكالماتشان رئن

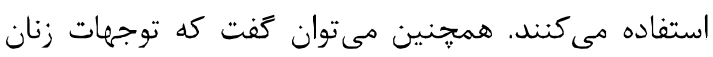
حول زندگى خصوصى و حوزه خانه و خانواده معطوف است و از طرف ديخر تمركز مردان بيشتر بر موضوعات خارجى در در 
رايانامهاى كاربران، مورد استفاده قرار كرفته است [1]. در اين بررسى از ويزگكىهاى مستقل از متن مانند ويزگكى هاى

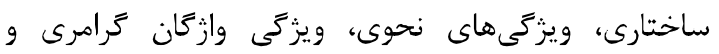
ويزُكىهاى مبتنى بر وازثه و مبتنى بر حروف استفاده شدئ

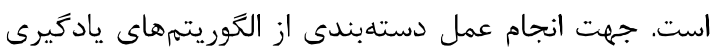

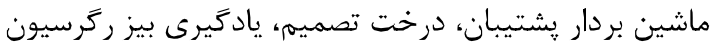
Adaboost ،Logistic

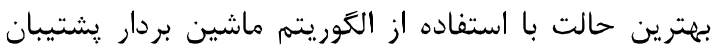

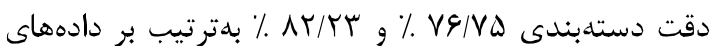

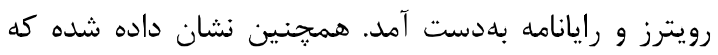

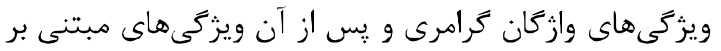

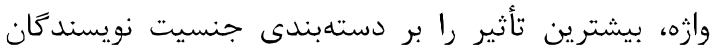

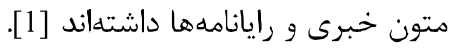
يزوهش ديكَرى در اين زمينه توسط حانحَ بر محتويات

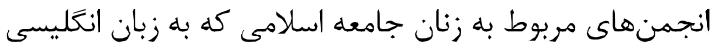

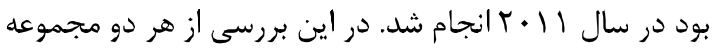

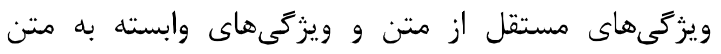

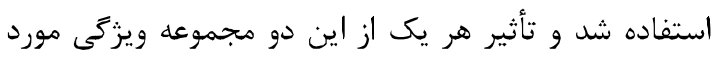

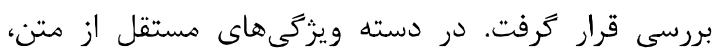

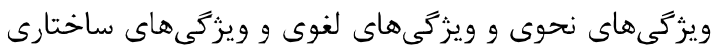

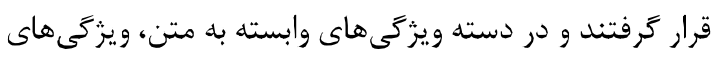

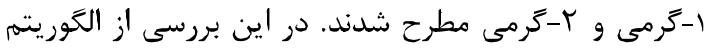

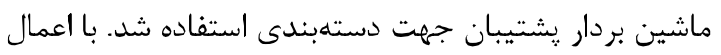

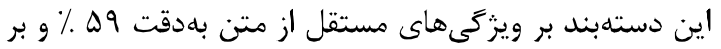

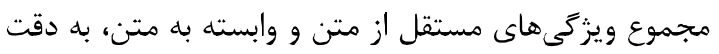

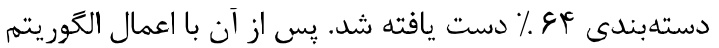
انتخاب ويزگى بهره اطلاعاتى بر مجموع كل ويزَّى هاى وابسته

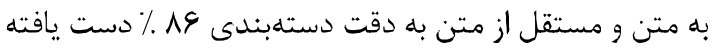

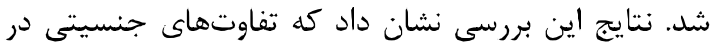

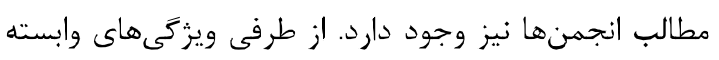

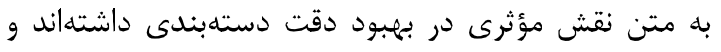

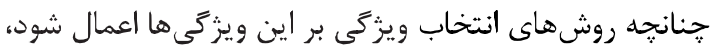

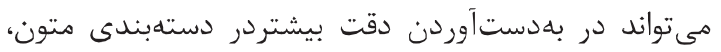

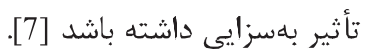
در موضوع تشخيص جنسيت نويسنده، مطالعه ديكرى

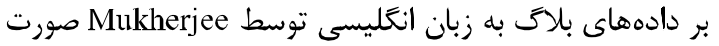

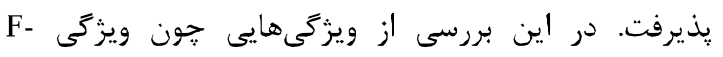

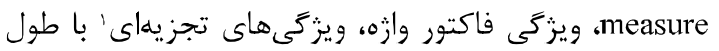

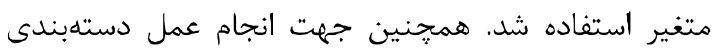

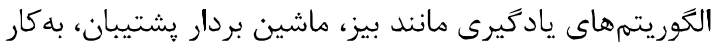

'Part of Speech(POS)
ادبى و مقالات ندارند، لذا ارائه راهكارهاى جديد جهت دستهبندى اين گونه متون مورد نياز است.

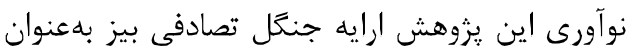
روشى نوين جهت دستدبندى و بهكاركيرى آن براى مسأله تشخيص جنسيت نويسندكان است.

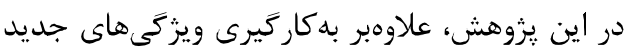

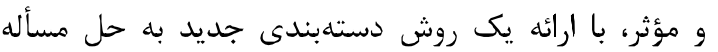

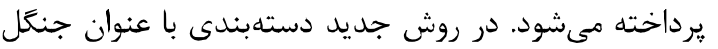

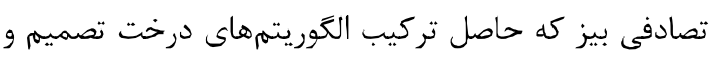

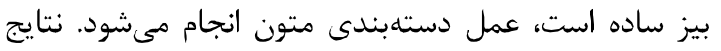

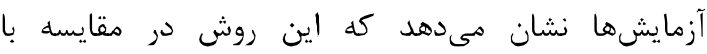

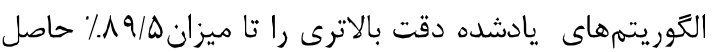

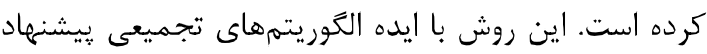

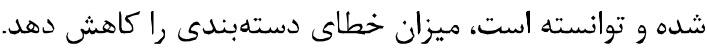

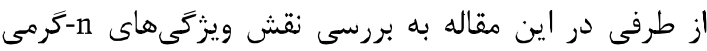

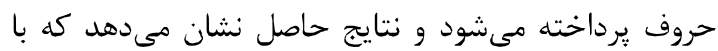

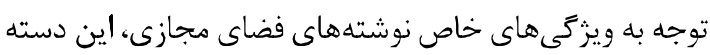

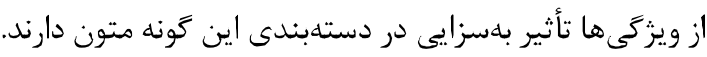

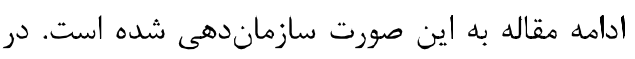

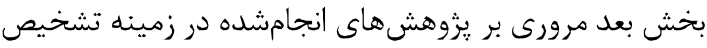

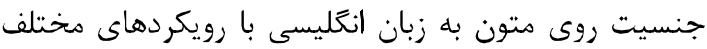

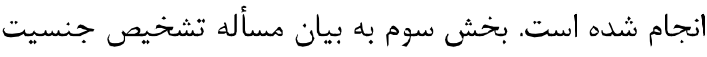

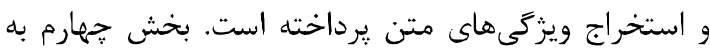

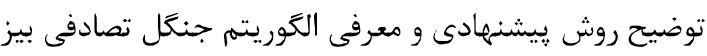

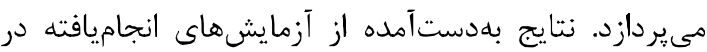

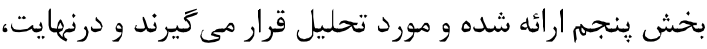
بخش ششم به جمعبندى مقاله اختصاص دارد.

\section{r- مرورى بر كارهاى انجامشده}

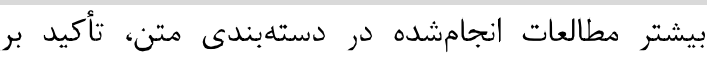

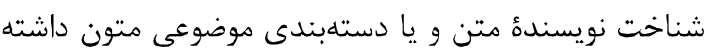
و مطالعات كمترى در زمينه تفكيك جنسيت نويسندكان صورت كرفته است.

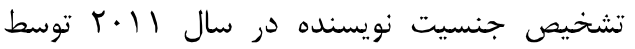

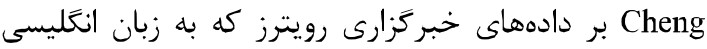

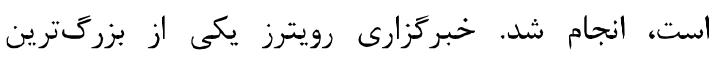

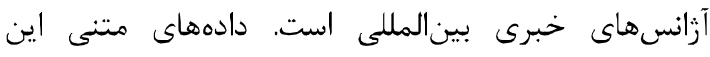

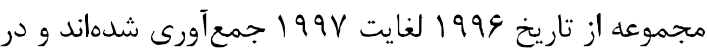

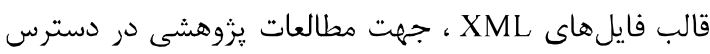

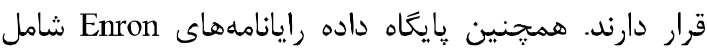


r- مسأله تشخيص جنسيت

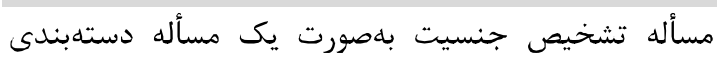

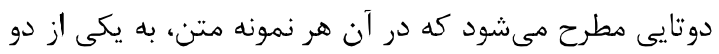

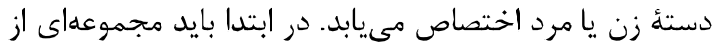

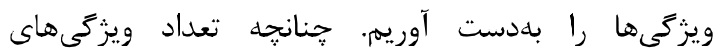

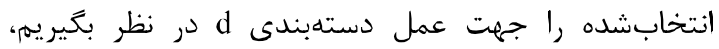

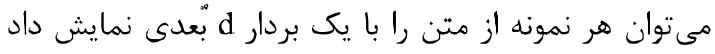
كه d تعداد كل ويزّكىهاى بهدست آمده است. رياضى كونه مىخواهيم تابع بهدست آوريم بلهطورى كه مجموعه از نمونهها و

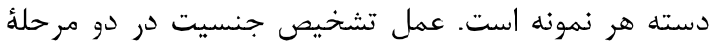
آموزش و آزمايش انجام مىشود، مرحلة آموزش شامل دئل

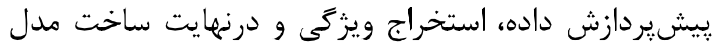

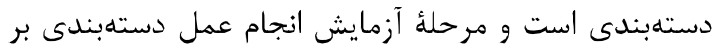

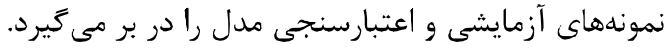

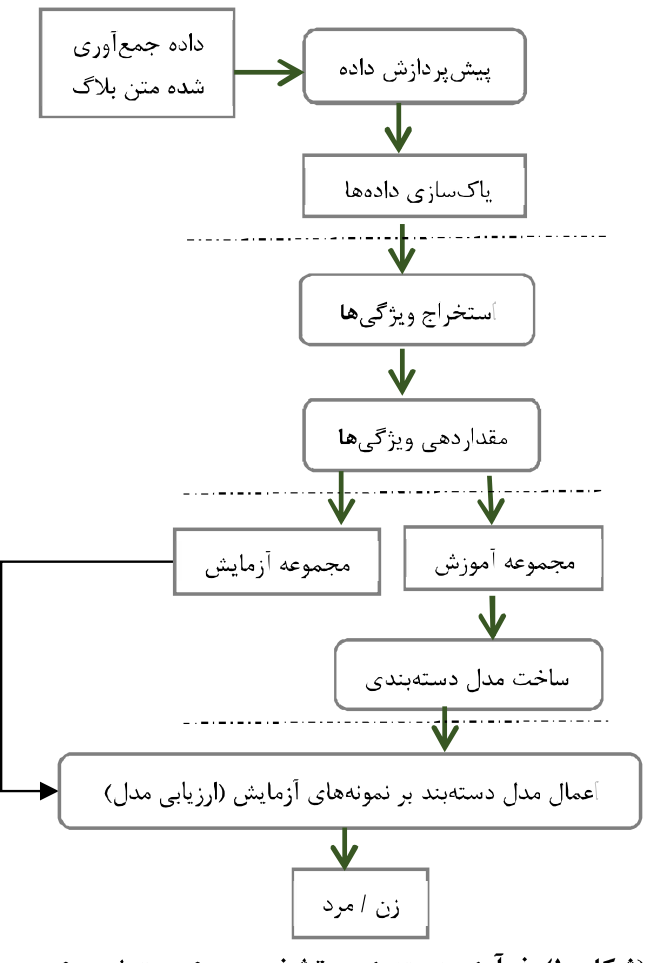

(شكل -1): فر آيند دستهبندى تشخيص جنسيت نويسنده

(Figure-1): Classification process of author gender identification

بهطور كلى فرآيند تشخيص جنسيت را مىتوان به جهار مرحله تفكيك كرد:

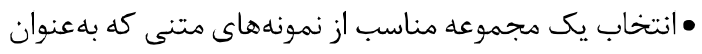
يايخاه داده استفاده شود.
كَرفته شدند. در اين بررسى يك روش انتخاب ويزَّى تركيبى

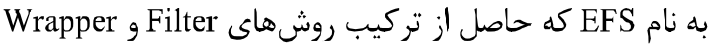

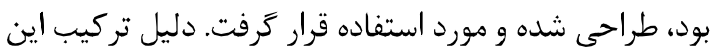
دو روش كاهش خطاهاى هر يك از روشهاى Filter و و

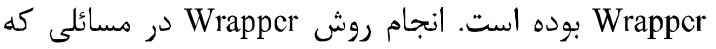

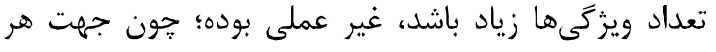

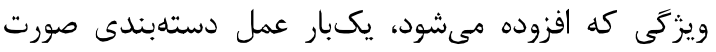
مى گيرد تا مفيدبودن ويزَى بررسى شود. از طرف ديخر در

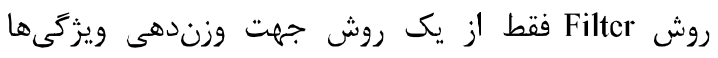

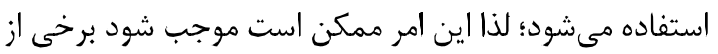

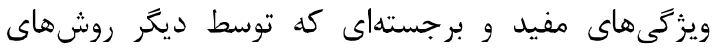

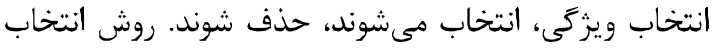

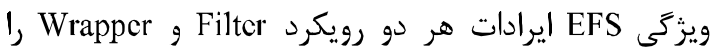

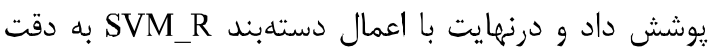
MN/DS ٪ دست يافته شد. همجزنين در اين بررسى نشان داده

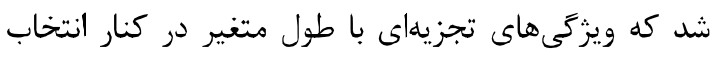

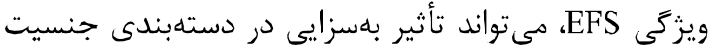
داشته باشد؛ بهطورىكه بدون استفاده از ويزگى يادشده و

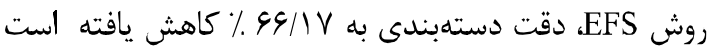

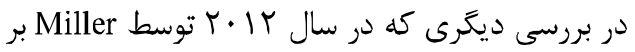
دادههاى شبكه اجتماعى توييتر به زبان انخَليسى انجام شد از داز

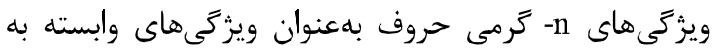

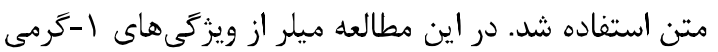
تا ه-كرمى جهت دستهبندى متون استفاده كرد. از آنجا كه

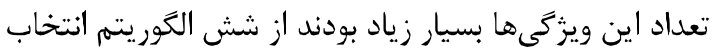

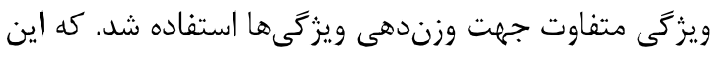
امر منجر به توليد شش زيرمجموعه از ويزگكىهاى برتر

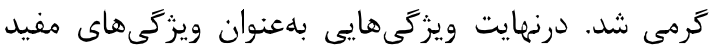

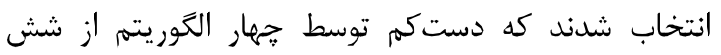
الكوريتم انتخاب ويزّكى، بركزيده شده بودند. يس از از اعمال

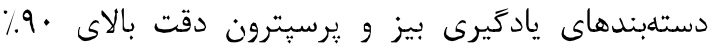

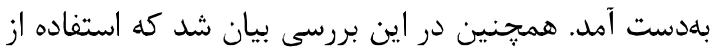

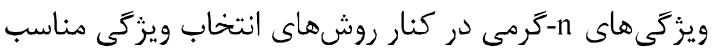
مىتواند در دستهبندى متون مفيد باشد [2]

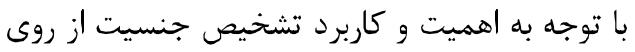

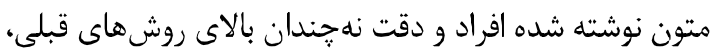

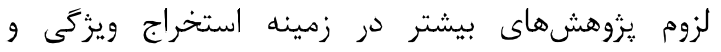

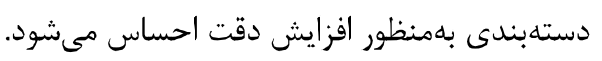


از انواع متفاوتى از ويزُكىها، جهت دستهبندى استفاده شود. קِيجيد

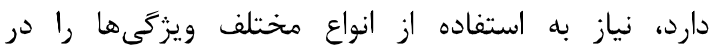

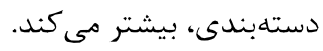

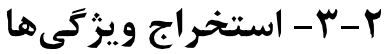

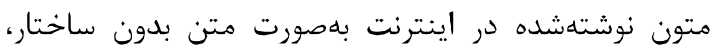

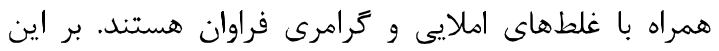

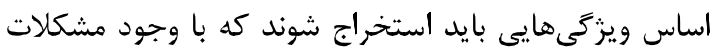

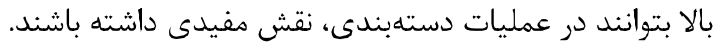

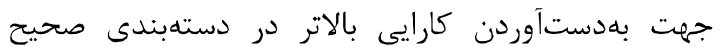

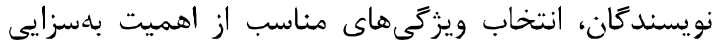

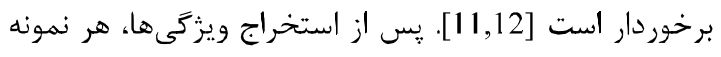

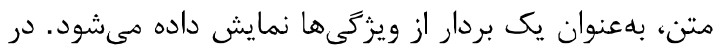

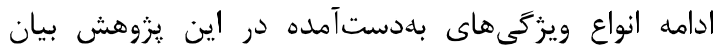

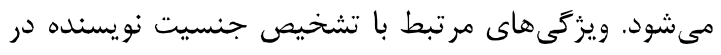

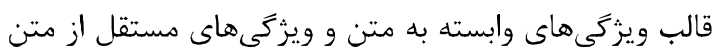

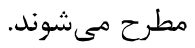

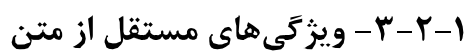

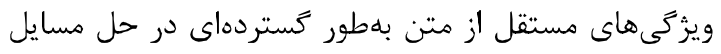

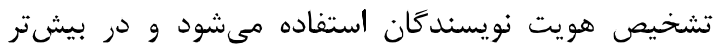

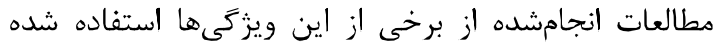

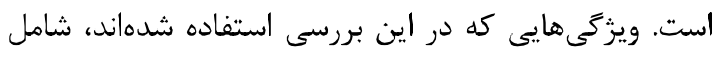

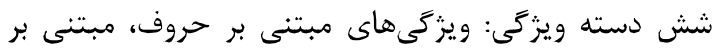

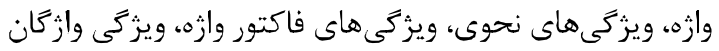

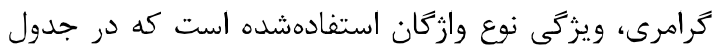

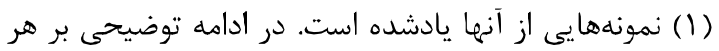

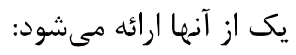

\section{ويزَّى هاى مبتنى بر حروف: اين ويزَّى ها بلهصورت}

كسترداى در مسايل تشخيص نويسنده استفاده مىشود؛

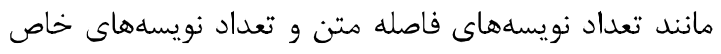

مانند \% \& \& [13]

ويزَكى هاى مبتنى بر وازٔه: در طول جهار دها

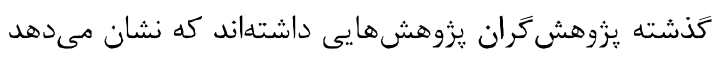

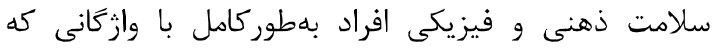

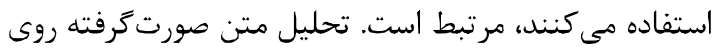
اين هطالعات نشان مىدهد كسانى كه تمايل بيشترى در دران

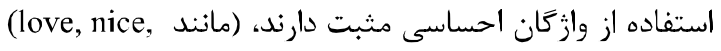

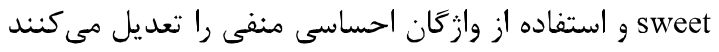

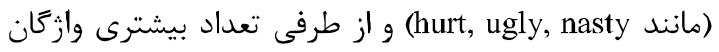

•استخراج و انتخاب ويرگكىهايى كه بتوانند جداكنندهاى خوبى محسوب شوند. • ساخت يك مدل دستهبندى جهت انجام عمل دستهبندى إندادي

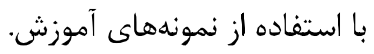
•اعمال مدل ساختهشده بر نمونههاى آزمايش و ارزيابى أموزي مدل. - مدال در شكل (1) اين مراحل مشاهده مىشود.

\section{1-r - خصوصيات متون فضاى مجازى}

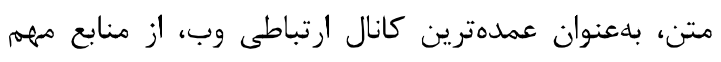
براى رديابى هويت در فضاى مجازى است. هر هندي

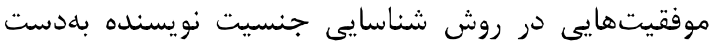

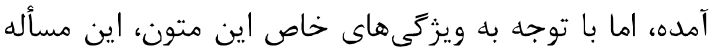

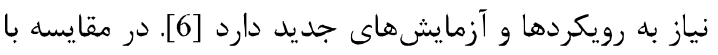

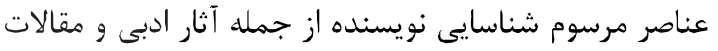

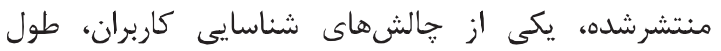

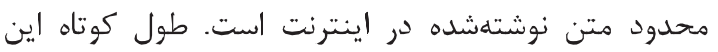

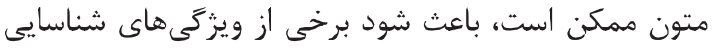

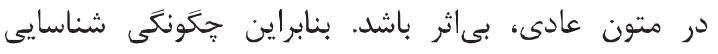

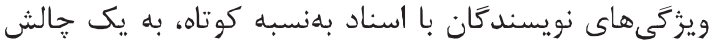

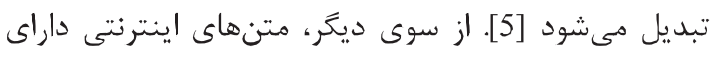

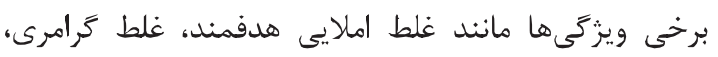

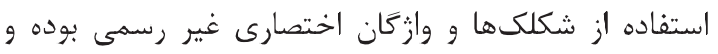

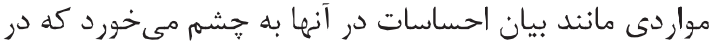

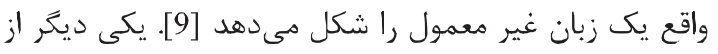

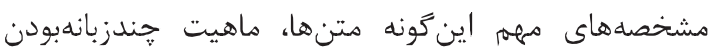

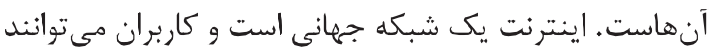

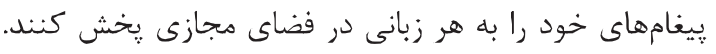

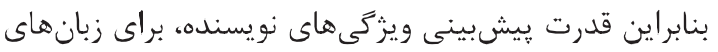

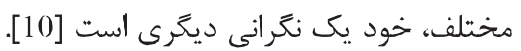

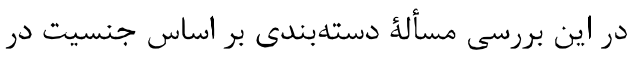

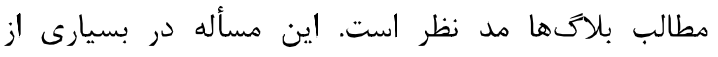

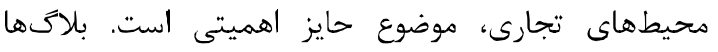

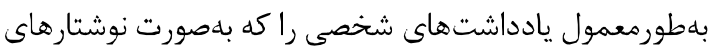
غير رسمى هستند، شامل مى شود. با رشد سريع تعداد باد بلاكَها

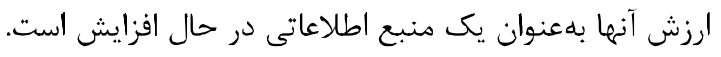

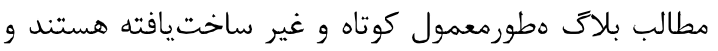

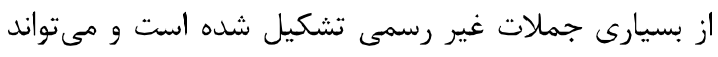

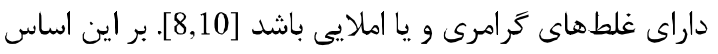

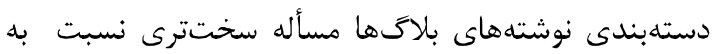

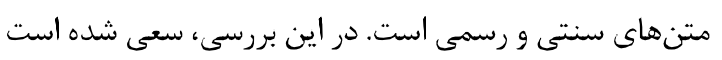


(جدول -(): نمونههايى از ويثَّى هاى مستقل از متن

(Tablc-1): Samples of text independent features

\begin{tabular}{|c|c|}
\hline توصيف ويزكى & ويثزى \\
\hline تعداد كل نويسهها & \multirow{7}{*}{ مبتنى برحى هاى } \\
\hline تعدان نويسههاى حرفى (a,b,...z) & \\
\hline تعدل د نويسههاى با حروف بزرى & \\
\hline تعد د نويسه هاى عددى & \\
\hline تعدد نويسههاى Space ستفاده شده & \\
\hline Tعد د نويسه Tab Space & \\
\hline تعداد نويسههاى خاص \%, \$ & \\
\hline تعدد كل وزگًان ستفاده شده درهر متن & \multirow{5}{*}{ 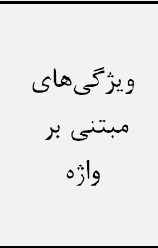 } \\
\hline متوسط طول ورز5ان (به نويسه) & \\
\hline غناى وزگًان & \\
\hline وازَّان بزرَتر از 4 نويسه & \\
\hline تعداد وازگكان كوتاه (ا تا س نويسه) & \\
\hline تعداد نويسه كيومه تك & \\
\hline تعداد نويسه كاما , & \\
\hline تعدد نويسه زقطه . . & \\
\hline تعدد نويسه كولون : & \multirow{3}{*}{ ويزَى هاى } \\
\hline تعدد نويسه سمى كولون ; & \\
\hline تعداد نويسه علامت سؤال ؟ & \\
\hline تعداد علامت سؤال حندتايى ؟؟؟ & \\
\hline تعداد علامت تعجب ! & \\
\hline تعداد علامت تعجب جندتايىى "! & \\
\hline تعداد سه نقطه ت & \\
\hline a, an, the تعداد وازگكان & \\
\hline yes, okey تعداد وازًّان شبه جمله مانند & \\
\hline 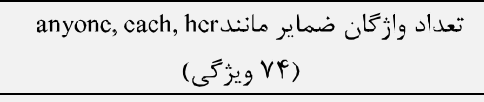 & \multirow{2}{*}{ ويزخى كرامرى } \\
\hline 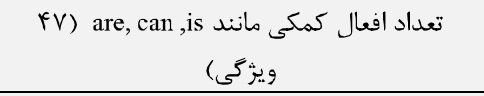 & \\
\hline 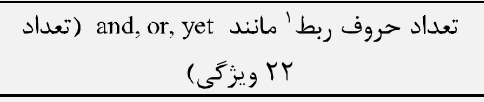 & \\
\hline 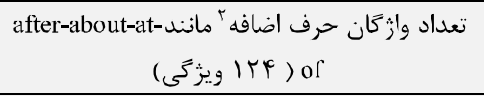 & \\
\hline وازكانى كه به able ختمم مىشوند. & \multirow{3}{*}{ ويزگ نوع وازى } \\
\hline وازگًانى كه به al ختم مىشوند. & \\
\hline وازَّانى كه به full ختم مى & \\
\hline وازٔكانى كه به ible ختم مىشوند. & \\
\hline وازَٔانى كه به ic ختمم مىشوند. & \\
\hline وازّكانى كه به ive ختمم مىشوند. & \\
\hline وازَّانى كه به less ختم مىشوند. & \\
\hline وازًَانى كه به ly ختم مىشوند. & \\
\hline وازگكانى كه به ous ختم مىشوند. & \\
\hline
\end{tabular}

${ }^{1}$ conjunction words

${ }^{2}$ Adposition words
شناختى بهكار مىبرند (مانند cause, know) از مزاياى

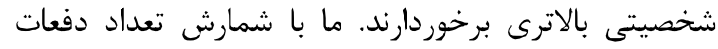

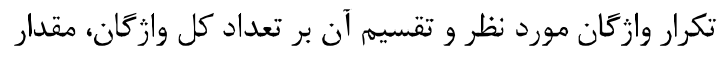
ويزگى هاى مبتنى بر وازه را بهدست مى آوريهم. ويزَّىهاى نحوى: اين دسته از ويزَّىها ساختار

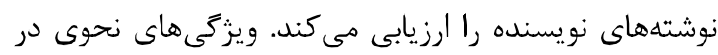

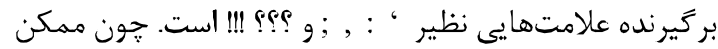

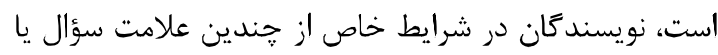

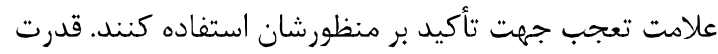

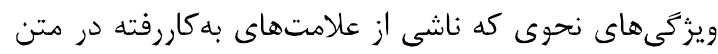
است، از تفاوتهاى عادات نوشتارى زن و و مرد در استفاده از از إنائ

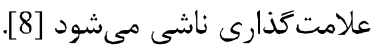

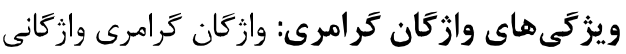

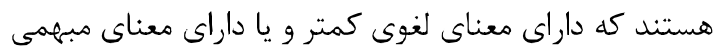

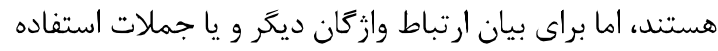

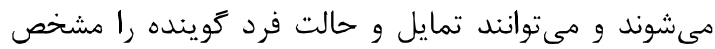

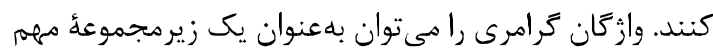

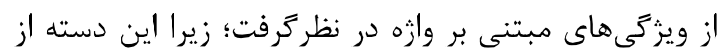

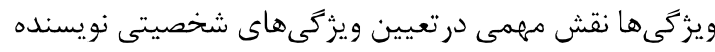
دارند.

ويخَّى نوع وازَّان استفاده شده: اين دسته ويزَّى،

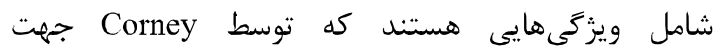

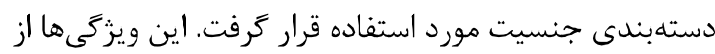

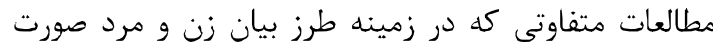

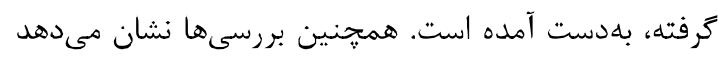

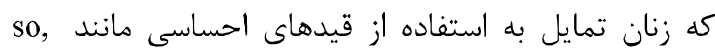
terribly, awfully

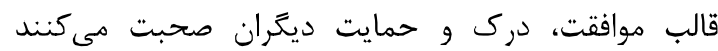

ويزَى فاكتور وازه: تحليل و بررسى فاكتور وازه، به

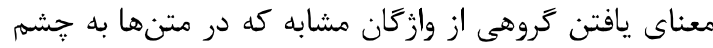

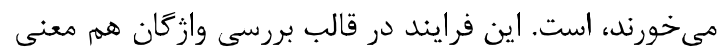

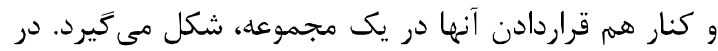
يزروهشى كه توسط Argamen انجام شده است، وازئان تحليل شدند و در قالب بيست فاكتور - كه هر فاكتور نشاندهنده

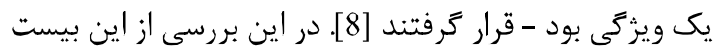
فاكتور بهعنوان بيست ويزگى استفاده شده است. استخراج

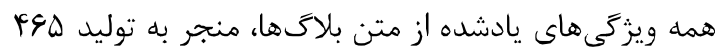
ويزگ

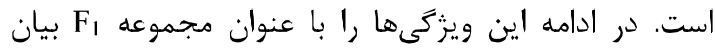
مى كنيم. 


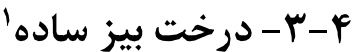

ساخت درخت بيز ساده همانند ديكر درختهاى تصميم شروع

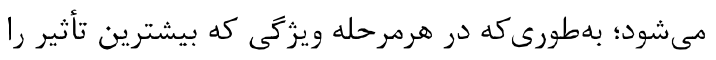
در تفكيك دستهها داشته باشد، انتخاب مى دشود. تا زمانى كهد ميزان سودمندى گره جديد در جداسازى، از ميزان سودمندى

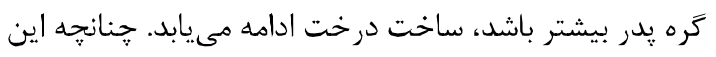

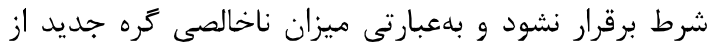

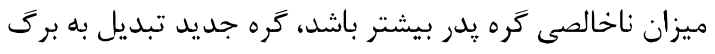

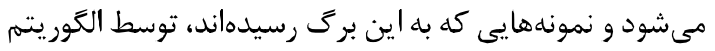
يادكيرى بيز دستهبندى شده و دستأ نمونه مورد نظر

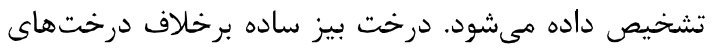

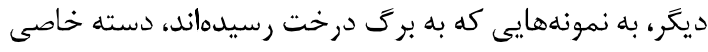
نسبت نمىدهد؛ بلكه جهت دستهبندى اين نمونهها از از

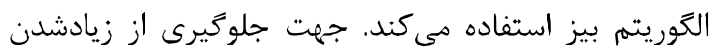
تقسيم در درخت، مشخص شد درصورتى تقسيم ادامه يابد كه كاهش تقريبى خطا بيشتر از هـ بوده و تعداد نمونهها در كره مورد نظر دست كم سى نمونه باشد [15]. شكل (؟) اين درخت را انمايش ميدهد.

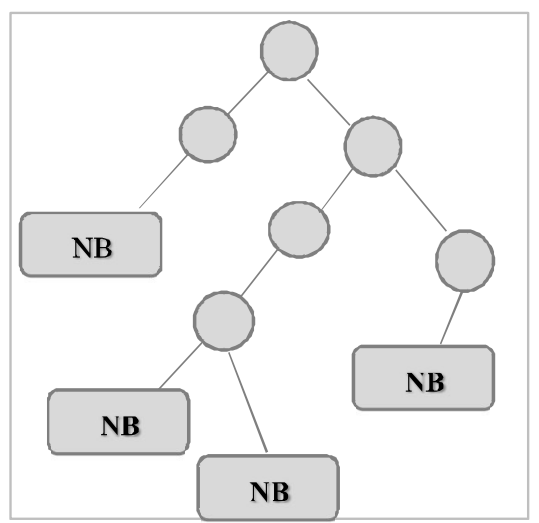

(شكل-Y) : درخت بيز ساده

(Figure-2): Naïve Bayes tree

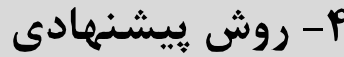

در اين بخش روش رِيشنهادى دستلهبندى نمونهها با عنوان

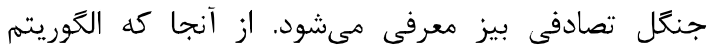

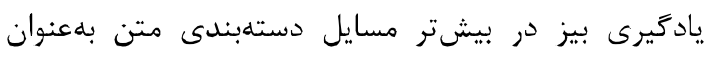

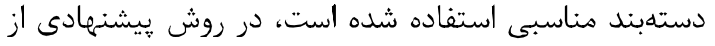

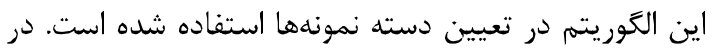
اين قسمت به بيان روش توليد جنكَ تصادفى بيز مى يردازيمه.

${ }^{1}$ NB Tree

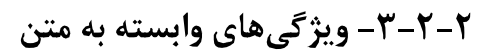

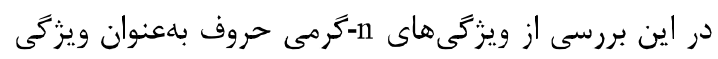

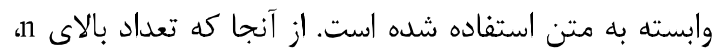

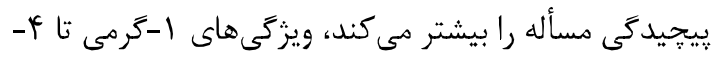

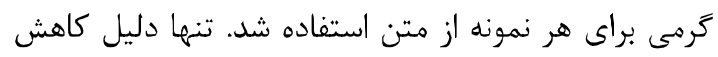

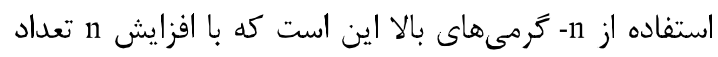

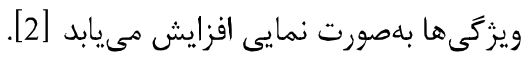

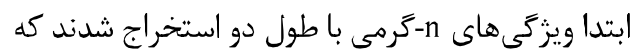

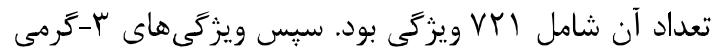

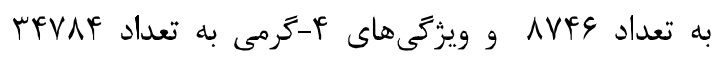

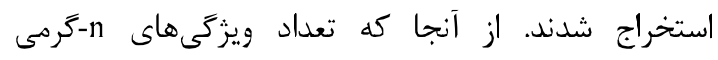

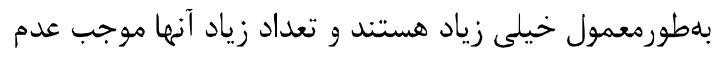

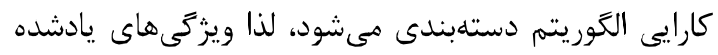

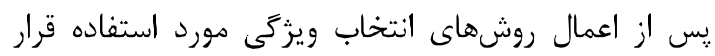

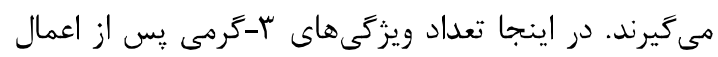

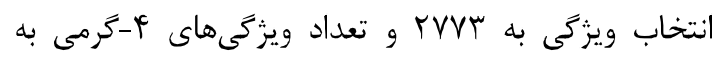
99 9 كاهش يافته و مورد استفاده قرار كرفتند.

\section{r-r- مقداردهى ويز كى ها}

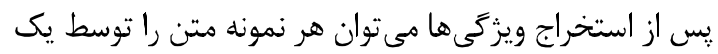

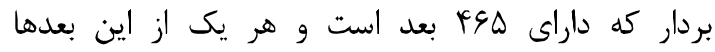

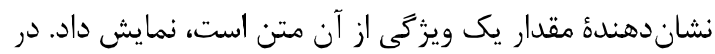

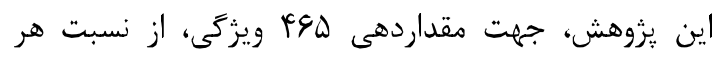

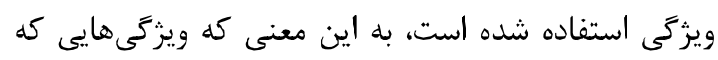

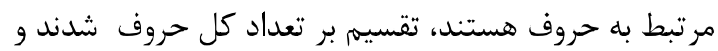

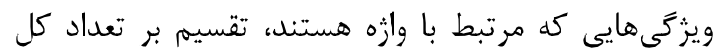
وازكان شدند.

جهت اطمينان از اينكه تمام ويزگى ها به نسبت

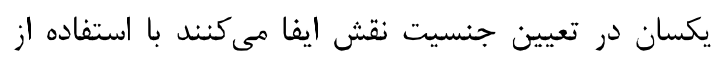

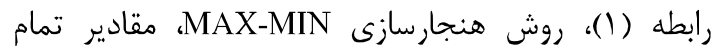

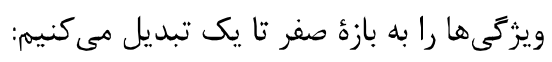

Normalized $\left(\mathrm{x}_{i j}\right)=\frac{\mathrm{x}_{i j}-\min \left(\mathrm{x}_{j}\right)}{\max \left(\mathrm{x}_{j}\right)-\min \left(\mathrm{x}_{j}\right)}$

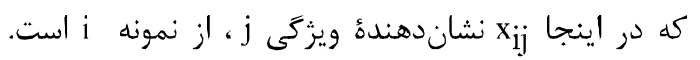
همجنين (xin (xj max(xj) 
در شكل (ז) مراحل ساخت و آزمايش روش

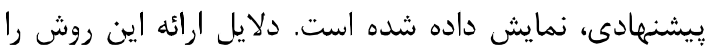
مى توان با موارد زير بيان كرد:

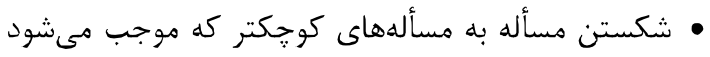
الكوريتم دستهبندى عمل يادَّيرى مدل را بهتر انجام دهد.

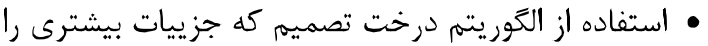
در زمان يادخيرى لحاظ مى كند.

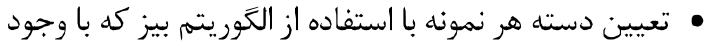
سادىى، در دستهبندى متون بهطورمعمول دقت خوبى ارائه مى دهل. • دسته هر نمونه توسط جندين مدل تعيين مىشود و در

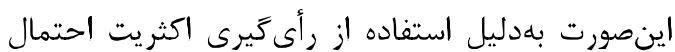
خطا در تشخيص دسته نمونه كاهش مى يابد.

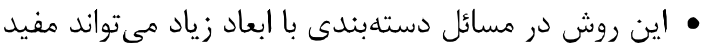

(جدول-Y): يارامترهاى الثوريتم يِيشنهادى جنگل تصادفى بيز (Table-2): Parameters of proposed Bayes Random Forest

\begin{tabular}{|c|c|}
\hline مقدار & هارامتر \\
\hline تصادفى & روش انتخاب ويزّكىها \\
\hline • & تعداد ويزگىى ها (k) \\
\hline با جاى تذارى & روش انتخاب نمونهها \\
\hline \% 9 مجموعه آموزش & نسبت تعداد نمونهها (j) \\
\hline$n$ & دفعات تكرار \\
\hline درخت بيز ساده & للَوريتم يادكَير \\
\hline 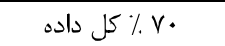 & مجموعه آموزش \\
\hline
\end{tabular}

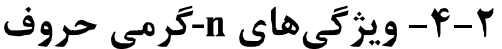

ييشبينى جنسيت از طريق متن در كذشتها، در درجهُ نخست

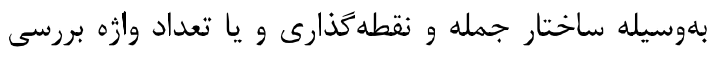

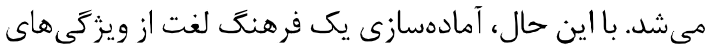

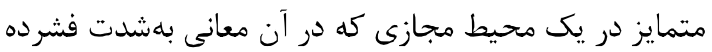

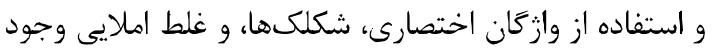

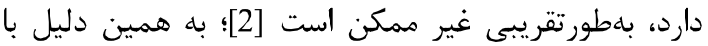

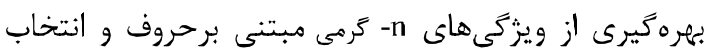

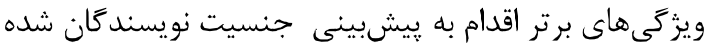

براى نشاندادن هر متن با استفاده از بردار ويزگى، از

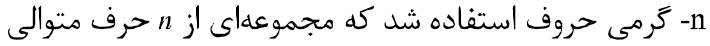
است. بلمنظور كاهش تعداد ويزگى هاى ا-ترمى، از مجموعه كامل وها حروف اسكى تعداد سى مورد كه در يايغاه داده

بلاكى استفاده شله است، انتخاب شدند. هركدام از

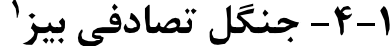

از آنجا كه در برخى مسايل دادهكاوى شكستن مسأله به

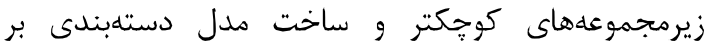
زيرمجموعههاى حاصل، منجر به يادگيرى بهتر الكَوريتم

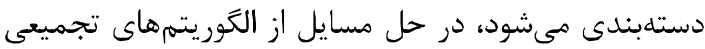
كه اساس كارشان بر اين اصل استوار است، استفاده مىشودي.

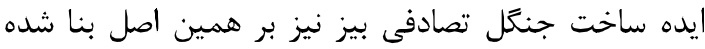

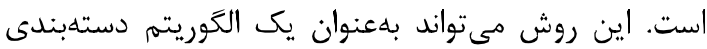

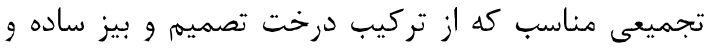
جنغل تصادفى تشكيل شده است، در مسايل دستهبندى ندي

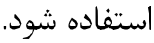

يارامترهاى اين الكوريتم در جدول (Y) نمايش داده شده است. مقدار يارامترهاى تعداد ويزّكى انتخابى و تعداد

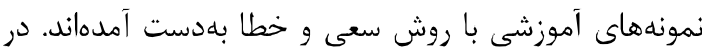

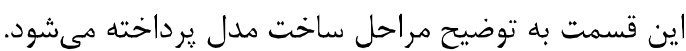
ابتدا از نمونههاى مجموعه آموزشى جهت مراحت مرحله

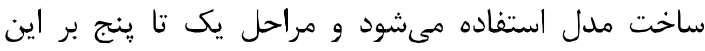

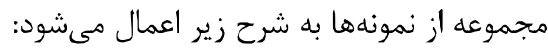

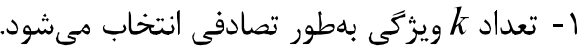

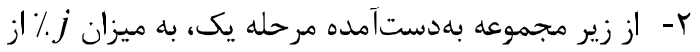

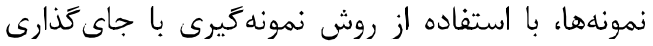

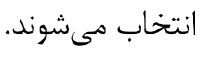

بـ الكَوريتم يادكير درخت بيز روى زيرمجموعه بهدستآمده

$$
\text { در مرحلة دو اعمال مىشود. }
$$

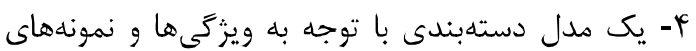

$$
\text { انتخابشده ايجاد و ذخيره مىشود. }
$$

ه- مراحل يك تا جهار به تعداد دفعات n مرتبه تكرار شده دئه

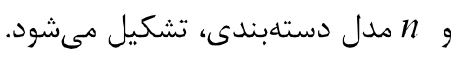

در مرحله بعد، مدلهاى ساختهشده بر نمونههاى آزمايشى

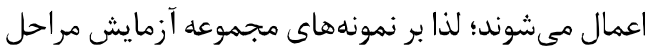

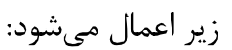

9- كليه نمونههاى آزمايشى به مدل دستهبند نخست داده مى شود و اين مدل، دستهٔ هر نمونه را مشخص مى كندا.

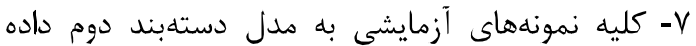
مىشود و اين مدل دستة هر نمونه را مشخص مئ كند.

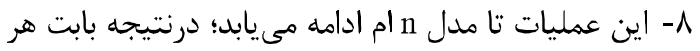

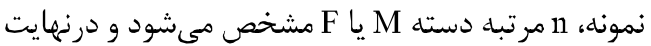
با درنظركرفتن "رأى اكثريت" دسته نهايى هر نمونه تشخيص داده مىشود.

${ }^{1}$ Bayesian Random Forest 


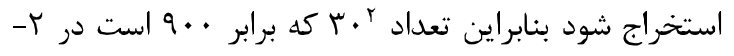

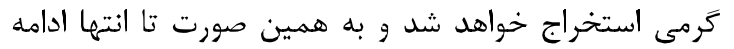

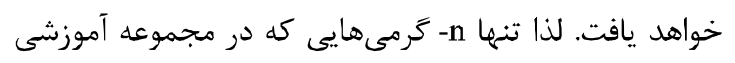
مشاهده شدند، بهعنوان ويزگى در نظر زرفته شدند. در اين

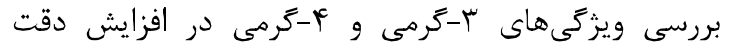
دستهبندى نقش مؤثرى داشتهاند؛ لذا در دو دسته مجزئ ا، جهرت بررسى دقت هر يك، در نظر گرفته شدند. nگرمىهاى بهدست آهده بهعنوان يك ويزّى مورد استفاده قراركرفت.

از آنجا كه تعداد بالاتر n ، يبيجيدگى مسأله را بيشتر

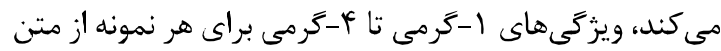

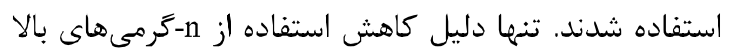

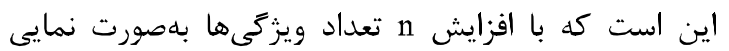

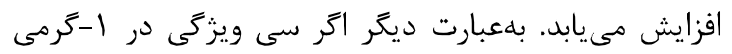
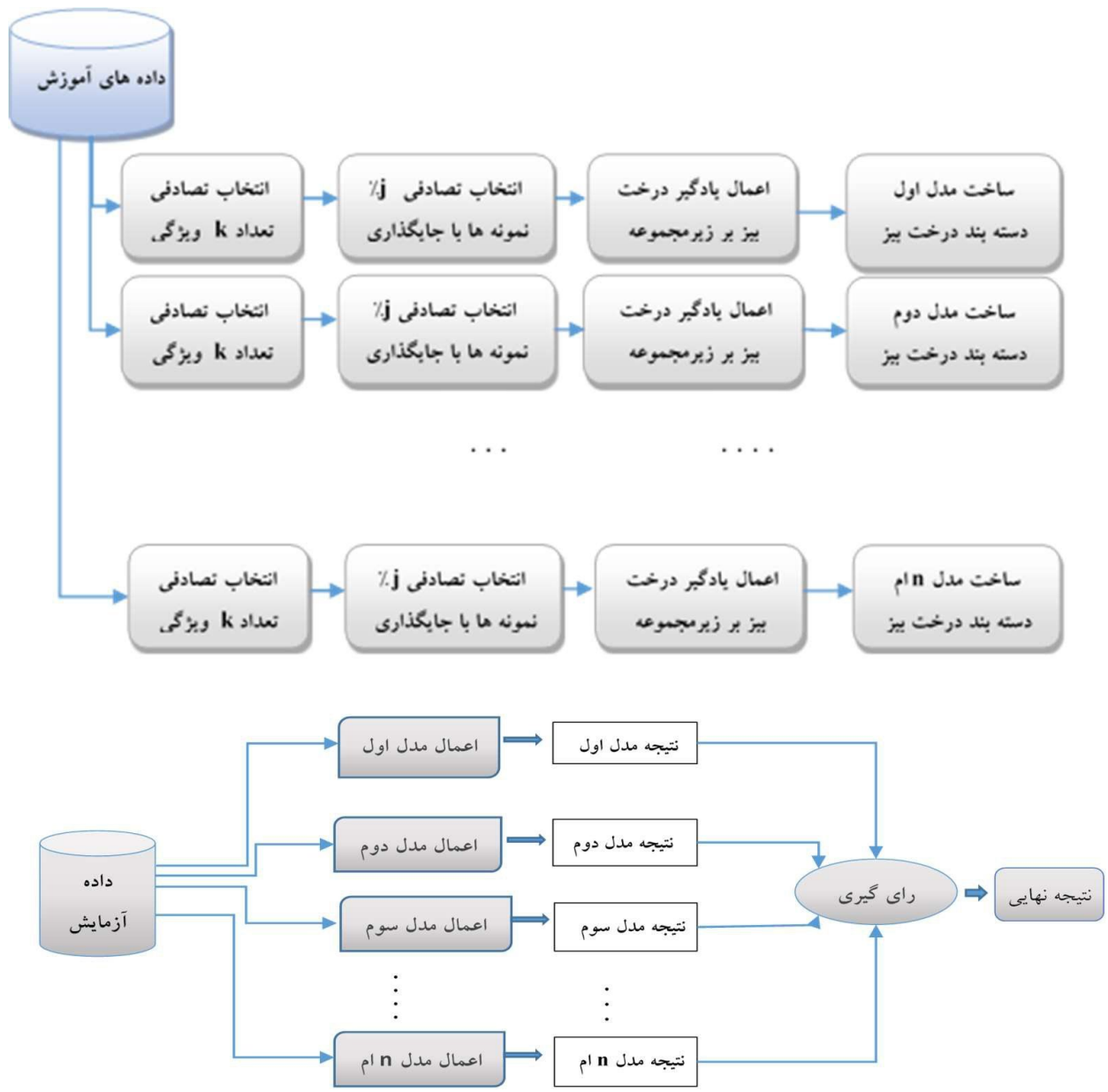

(شكل-Y): مر احل توليد الكوريتم يِيشنهادى و اعمال آن بر نمونه هاى آزمايش. الف - مراحل ساخت جنكَل تصادفى بيز ب- بهكاركيرى

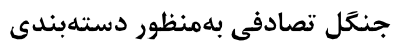

(Figure-3): Production steps of the proposed method and its running on the test samples (a) Production steps of Bayes Random Forest (b) Employing Random Forest for classification

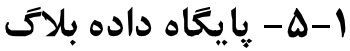

يايعاه داده استفادهده در اين ثروهش مربوط بـ اطلاعات

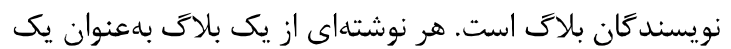
نمونه در نظر گرفته شده است. جهت جمعآورى متنهاى غير

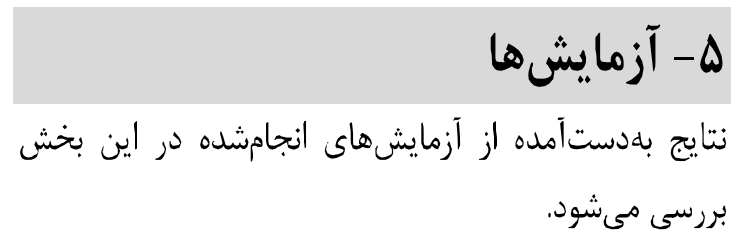




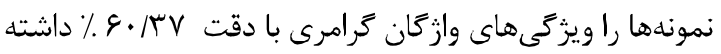

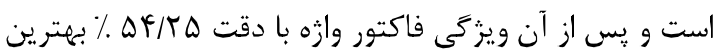

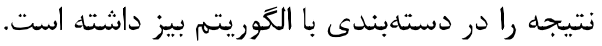

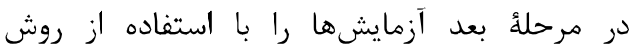
ييشنهادى جنگل تصادفى بيز ادامه مىدهيهم. ولى از آنجا كه از درخت بيز ساده در اين روش استفاده شده، ابتدا عمل

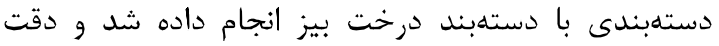

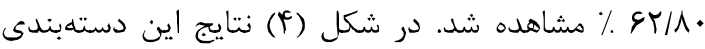

نشان داده شده است.

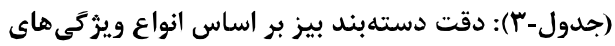

مستقل از متن

(Table-3): Accuracy of Bayes classifier based on different text independent features

\begin{tabular}{|c|c|}
\hline دقت دستهبندى بيز & انواع ويزُكى ها \\
\hline$\% \Delta 1 / 9 \vee$ & ويزگى هاى مبتنى بر حروف \\
\hline$\% \Delta T / \cdot V$ & ويزّكى هاى مبتنى بر وازه \\
\hline$\% \Delta r / q$. & ويرَّى هاى نحوى \\
\hline$\% \cdot \varepsilon \cdot / T V$ & ويزَى وازَّان گرامرى \\
\hline$\% \Delta F / T \Delta$ & ويزگى فاكتور وازه \\
\hline$\% \Delta r / r q$ & 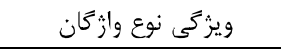 \\
\hline
\end{tabular}

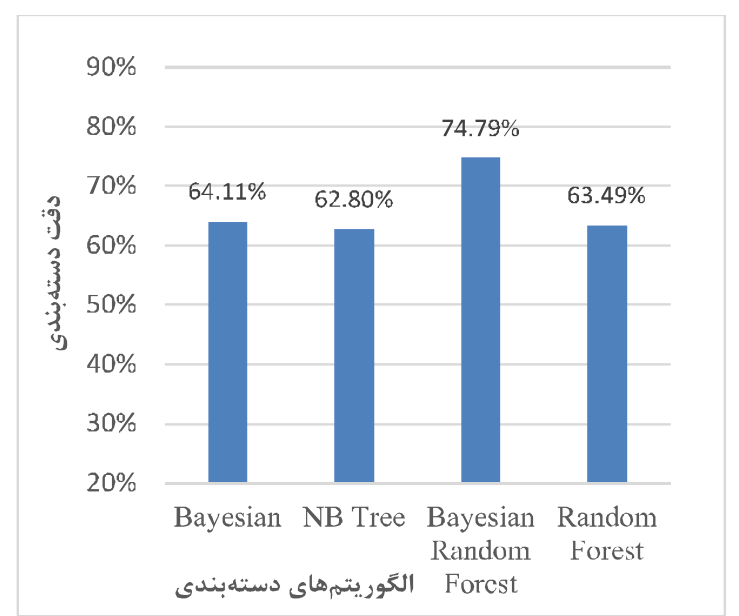

(شكل-f): دقت دستهبندى با الخَوريتمهاى بيز، درخت بيز،

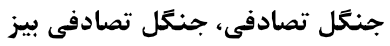

(Figure-4): Classification accuracy using Bayes, Bayes tree, Random Forest and Bayes random Forest

در ادامه، اقدام به ساخت جنگل تصادفى بيز با يارامترهاى مرتبط آن با استفاده از روش سعى و خطا شد. بهطورى كه در ابتدا ساخت هر درخت بيز با ده ويزگى (مقدار

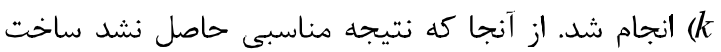

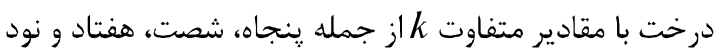
ويزگى ادامه يافت، كه بهترين نتايج مربوط به نود ويزگى بوده ماده

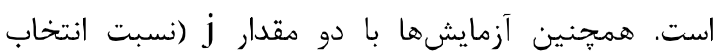

ساختيافتهاى كه در بلاتها نوشته شده است، از بسيارى از سايتهايى كه توسط كاربران مورد استفاده قرار مى گيرند، مانند blogger.com و استفاده شده است. اين مجموعه شامل rا ما بلاحت بوده است. نوشتههاى هر

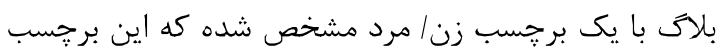
با بررسى صفحه يروفايل فرد بهدست آمده است. همهُنين در

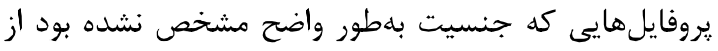

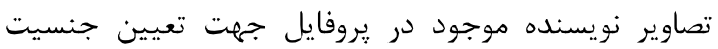
استفاده شده است [8].

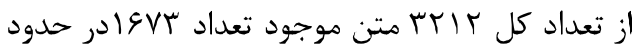

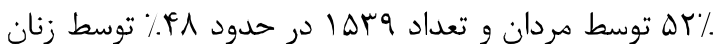
نوشته شده و sتوسط طول متن ها تعداد •له وازه براى مردان و • سب وازه براى زنان بوده است. يس از انجام مراحل استخراج ويزگى ونى و مقداردهى

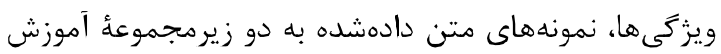

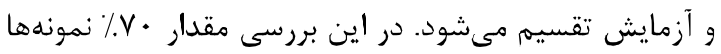

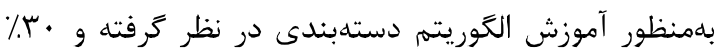

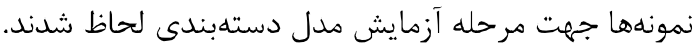

\section{Y-ه - بررسى تأثير جنگً تصادفى بيز}

با توجه به نتايج آزمايشهاى جنگل تصادفى بيز در دستهبندى و مقايسه با نتايج دستهبندهاى بيز، درخت بيز و جنسل

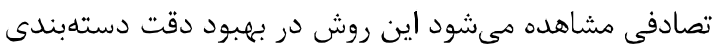

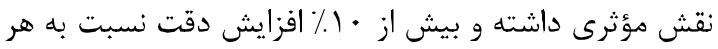
يك از الكوريتمههاى مذكور داشته است؛ لذا مىتوان كَفت اين روش مىتواند در كاهش خطاى دستهبندى نقش بهسزايى

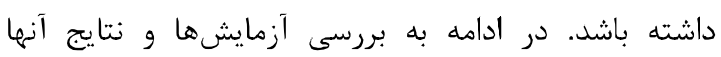
مىيردازيم.

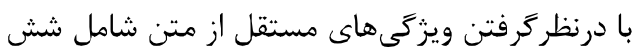

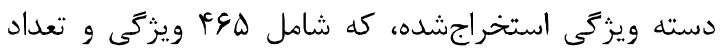

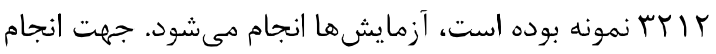

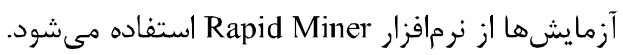
در مرحلة نخست، الكوريتم يادگيرى بيز بر نمونهها

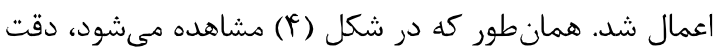

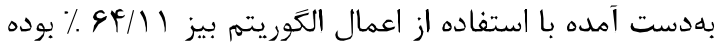
است.

در مرحله بعدى آزمايش، تأثير هر دسته از ويثزحى هاى

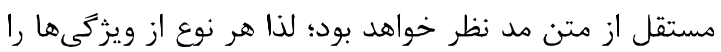

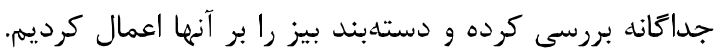

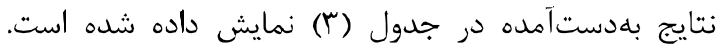
همانطور كه از نتايج بر مىآيد، بالاترين تأثير در تفكيك داديث 
جهت بررسى دقيقتر، در جدول (ه) مقايسهاى بين الكوريتهم جنكل تصادفى و روش يِيشنهادى جنكل تصادفى بيز

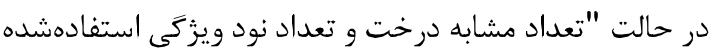

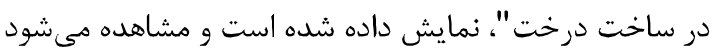
كه روش بيشنهادى در همه حالتها دقت بالاترى در دستهبندى داشته است.

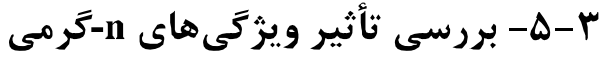

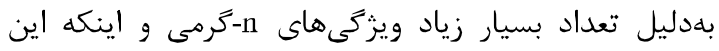
ويثگى ها تمام جزييات متون را استخراج مى كند، مىتوانند قدرت جداكنندگى خوبى در دستهبندى متون داشته باشند. از آنجا كه نوشتههاى فضاى مجازى به ميزان زيادى غلط املايى داشته و در آن شكلكها و وازَّان اختصارى عاميانه

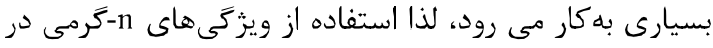
مقياس حروف، مفيد و مؤثر خواهد بود. اين بررسى نشان دهان داده است كه استفاده از اين نوع ويزگى دقت دستهبندى رونى را تاميزان

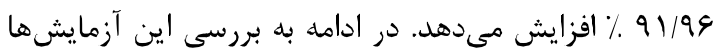

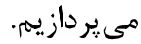
در اين مرحله از ويثزى هاى وابسته بله متن n- گرمى دئ

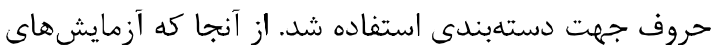
انجامشده نشان داد n-كرمىهاى با طول يك و دو دو تأثير

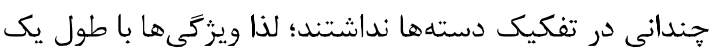
تا سه در يك مجموعه و ويزگى ها با طول هجهار در مجموعه

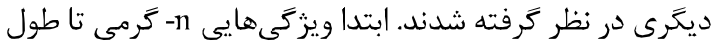

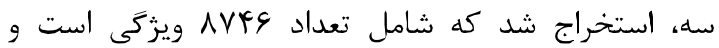
الكوريتم انتخاب ويزگى نسبت بهره اطلاعاتى بر آنها اعمال

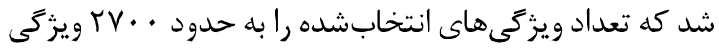
كاهش داده است. نتايج دستلهبندى توسط الكوريتم بيز،

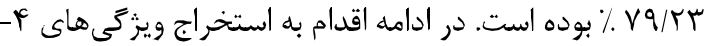

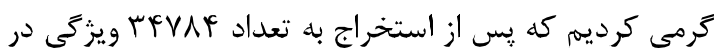

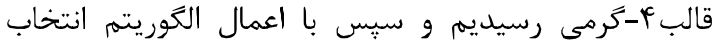

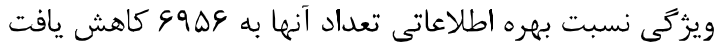

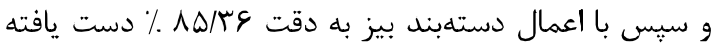

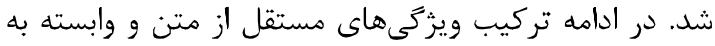

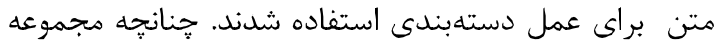

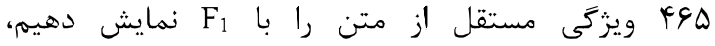
مجموعه +FF خواهد بود كه با اعمال الكوريتم انتخاب ويزگى نسبت بهره اطلاعاتى تعداد آنها به צس ال ويزگى كاهش يافت. يس از انجام

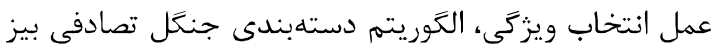

تصادفى نمونههاى آموزش) به ميزان • V٪ و •9٪ انجام داده

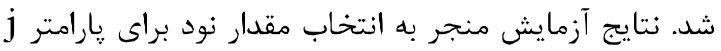

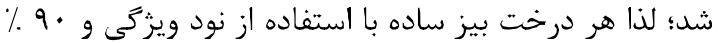
نمونهای آموزشى ساخته شد.

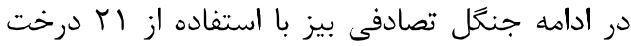

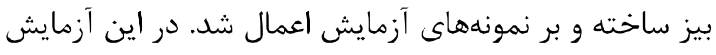

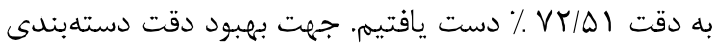

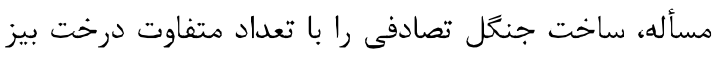

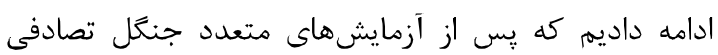

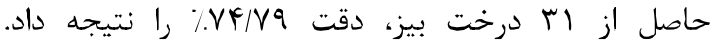

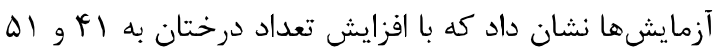
درخت، روند كاهشى در دقت دستهبندى خواهيم داشت.

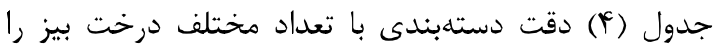
نمايش مى دهد.

(جدول-F): دقت رأى (Fيرى اكثريت بر جنگل تصادفى درختان بيز

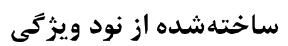

(Table-4): Accuracy of Majority vote in Bayes random forest

\begin{tabular}{|c|c|}
\hline جنَّل تصادفى درخت بيز & دقت نهايى "رأى اكثريت \\
\hline 11 ا درخت بيز & $\%$ VI/GA \\
\hline آ درخت بيز & $\% V Y(\Delta)$ \\
\hline اس درخت بيز & $\% V F / V q$ \\
\hline ائ درخت بيز & \% VYIAY \\
\hline اله مرخت بيز & $\%$ VT/T. \\
\hline
\end{tabular}

جهت بررسى كارايى روش يِيشنهادى در شكل (F)

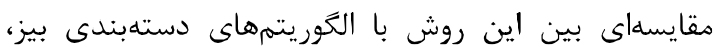

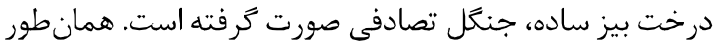

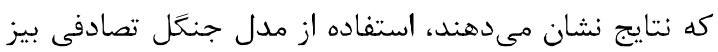
توانسته است، افزايش دقت خوبى را نسبت به الكَوريتم بيز و همجٍنين درخت بيز داشته باشد.

(جدول-ه): مقايسه دقت دستهبندى روش پيشنهادى و

جنغل تصادفى

(Table- 5): Comparison of proposed method and Random Forest based on accuracy measure

\begin{tabular}{|c|c|c|c|c|c|}
\hline & $\begin{array}{c}I 1 \\
\text { درخت }\end{array}$ & $\begin{array}{c}M \\
\text { درخت }\end{array}$ & درخت & $\begin{array}{c}F 1 \\
\text { درخت }\end{array}$ & $\begin{array}{c}\text { درخت } \\
\text { دات }\end{array}$ \\
\hline تصادفى & $81 / \pi 1$ & $9 r / \Delta q$ & $\varepsilon r / 4 q$ & $g r / \cdot V$ & gr/q. \\
\hline يَيشنهادى روش & $V 1 / 9 \Lambda$ & $V Y|Q|$ & $V F / V q$ & VT/AT & $V T / Y$. \\
\hline
\end{tabular}


و اين بار عمل دستهبندى جنسيت نويسندكان بلاك با دقت

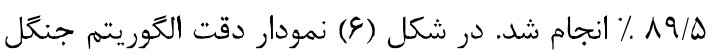
تصادفى بيز با هر دو مجموعه ويزگ از آنجا كه تشخيص جنسيت نويسنده در اين يثرهش

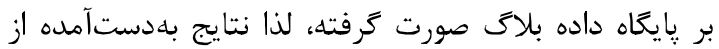

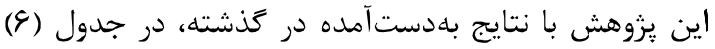

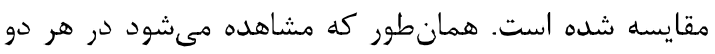

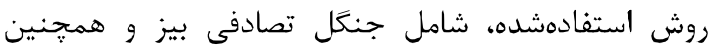
استفاده از ويزگى هاى n-گرهى حروف در كنار دستهبند بيز، دقت بالاترى نسبت به بررسى انجامشده در كذشته بهدئ آمده است.

(جدول-9): مقايسه يثروهش حاضر با بررسى انجامشده در

كذشته بر متن هاى بلاكت

(Table-6): Comparison of proposed method with other text

\begin{tabular}{|c|c|c|c|}
\hline \multicolumn{4}{|c|}{ blog researches } \\
\hline & ويزگ استفاد مورد & دستهوريندى & دستهبندى دقى \\
\hline \multirow{3}{*}{ توسط انجامشده } & \multirow{3}{*}{ 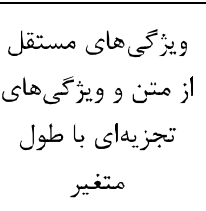 } & بيز ساده & $\% \mathrm{~V} / \Delta \mathrm{V}$ \\
\hline & & ماشين بردار & $\% \wedge G / Y F$ \\
\hline & & SVM_R & $\% \wedge \Lambda / \Delta Q$ \\
\hline \multirow{2}{*}{ ريشنهادى روش } & زيزّكى هاى مستقل و مترهى & \multirow{2}{*}{ تصادفى بيز } & $19 \% / 0$ \\
\hline & 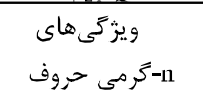 & & $\% 91 / 98$ \\
\hline
\end{tabular}

در جدول (V) مقايسه زمانى جنكَ تصادفى بيز با روش

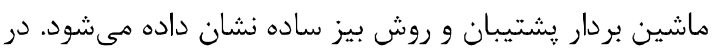
اين جدول زمان آموزش مدل و متوسط زمان آزمون براى هر نمونه نمايش داده مي رشود.

(جدول-V): مقايسه زمانى روش جنكل تصادفى بيز (Table-7): Time comparison of Bayes Random Forest

\begin{tabular}{|c|c|c|}
\hline تست زثان & 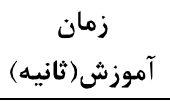 & روش دستهبندى \\
\hline r & $\varphi$ & جنكل تصادفى بيز \\
\hline 1 & $\Delta$ & ماشين بردار يشتيبان \\
\hline 1 & 9 & بيز ساده \\
\hline
\end{tabular}

\section{و- نتبحه}

در اين مقاله يك الكوريته جديد دستهبندى با عنوان جنكل تصادفى بيز ارائه شد كه در دستهبندى متون با استفاده از ويزخى هاى مستقل از متن توانسته است، بهبود خوبى در دقت دستدبندى نسبت به الكوريتمهاى مشابه داشتد باشد.
را اعمال كرده و دقت دستهبندى 91/91\% بهدست آهد. شكل

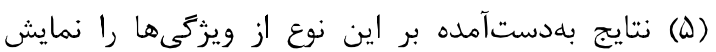

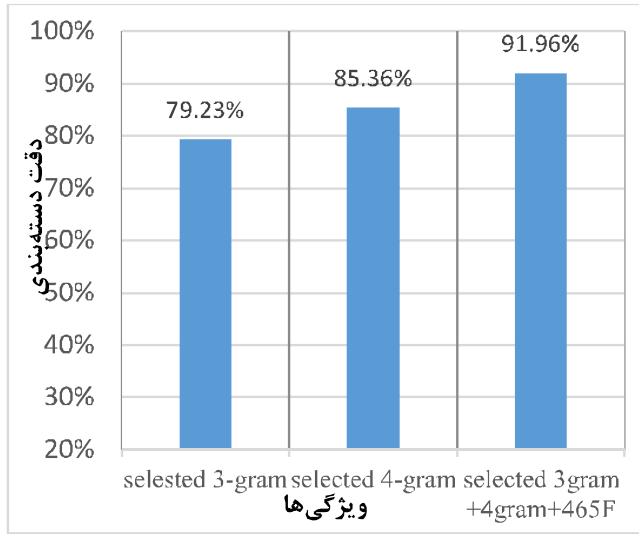

(شكل -ه) : دقت حاصل از ويثكى هاى n-كرمى و دستهبند بيز (Figure-5): Accuracy of using n-gram features and Bayes classifier

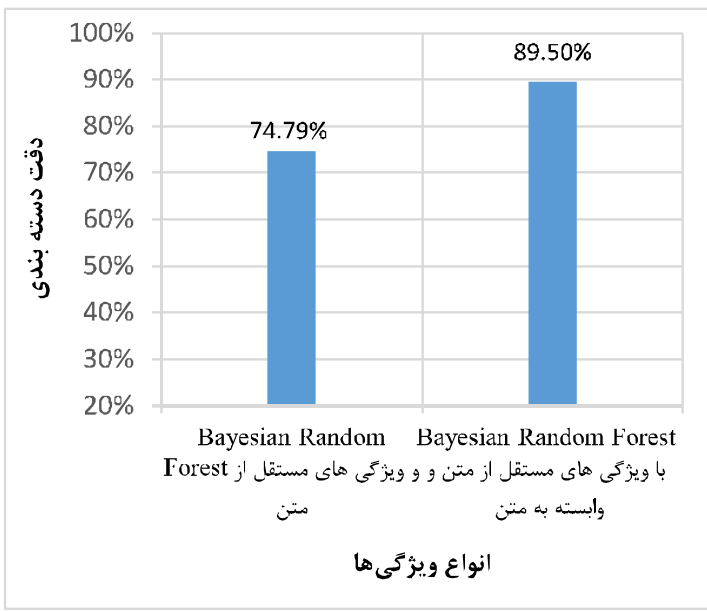

\section{(شكل-4): دقت الكوريتم بيشنهادى بر ويثزى هاى مستقل از متن و وابسته به متن}

(Figure-6): Accuracy of the proposed method with text dependent features and text independent features

بلمنظور اينكه در جنگل تصادفى بيز از ويثزَىهاى

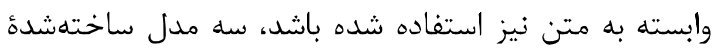
بالا، كه با استفاده از ويثزگىهاى وابسته به متن بهدست

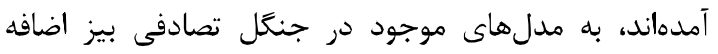

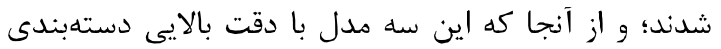

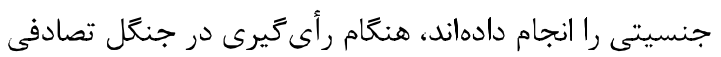

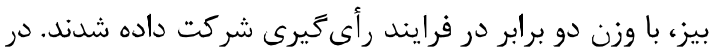

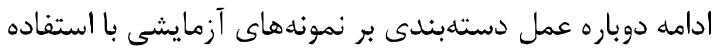

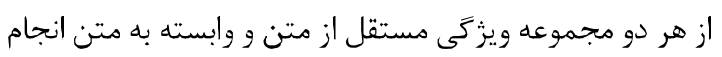


[6] A. Narayanan, H. Paskov and N. Z. Gong, "On the Feasibility of Internet-Scale Author Identification," IEEE Symposium on Security and Privacy, vol. 46, 2012.

[7] Y. Zhang, Y. Dang and H. Chen, "Gender classification for Web Forums, " IEEE Trans. On Systems, vol. 41, no. 4, 2011.

[8] A. Mukherjee and B. Liu, "Improving Gender Classification of Blog Authors," Conference on Empirical Methods in Natural Language Processing, 2010, pp. 207-217.

[9] S. Nowson and J. Oberlander, "The identity of bloggers: Openness and gender in personal weblogs," in proc. AAAI Spring Symposia Comput. Approaches Analyzing Weblogs, Stanford,CA, 2006.

[10] S. Hota, S. Argoman, M. Koppel, "performing gender Automatic stylistic analysis of shakespeare's characters," in Proc. Digital IIumanit. Conf, 2006, pp. 100-106.

[11] R.S. Forsyth and D.I. Holmes, "Feature finding for text classification," Literary Linguistic Compute., vol. 11, No. 4, pp. 163-174, 1996.

[12] M. Koppel, "Automatically categorizing written texts by author gender," Literary and Linguistic Computing, 2002.

[13] N. Cheng, X. Chen, R. Chandramouli and K.P. Subbalakshmi, "Gender Identification from Emails," computational intelligence and data mining, pp. 154-158, 2009.

[14] M. Corney, "Gender-preferential text mining of email discourse," 18th Annual Computer Security applications Conference, 2002.

[15] R. Kohavi, "Scaling Up the Accuracy of NaiveBayes Classifers a Decision Tree Hybrid," Second International Conference on Knoledge Discovery and Data Mining, 1996, pp. 202-207.

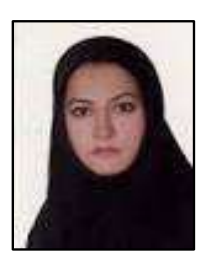

$$
\begin{aligned}
& \text { هديه ساجدى درجئ دكتراى خود را در }
\end{aligned}
$$

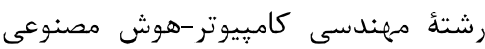

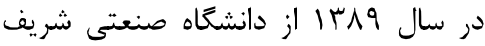

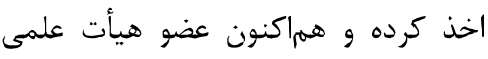

$$
\begin{aligned}
& \text { كروه علوم كامييوتر در دانشخاه تهران است. }
\end{aligned}
$$

زمينههاى يزوهشى ايشان عبارت است از: يادگيرى ماشين، داده كاوى و يردازش تصوير.

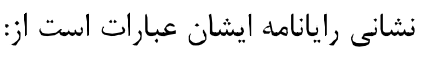

hhsajedi@ut.ac.ir

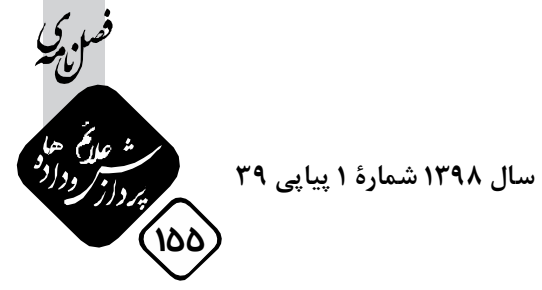

$$
\begin{aligned}
& \text { در اين روش از ايدهُ الخوريتهمهاى تجميعى و همجِنين } \\
& \text { روش بيز و درخت بيز ساده استفاده شده است. در ارائه اين } \\
& \text { روش، شكستن مسأله به مسألههاى كوجنتر كه موجب } \\
& \text { مىشود، التوريتم دستلبندى عمل يادگيرى مدل را بهتر انجام } \\
& \text { دهد و از طرفى تشخيص دستهُ هر نمونه با استفاده از الكوريتم } \\
& \text { بيز كه با وجود سادگى، در دستهبندى متون بهطورمعمول } \\
& \text { دقت خوبى ارائه مىدهد و همجنين كاهش ميزان خطاى } \\
& \text { دستهبندى كه يكى از دلايل استفاده از الخوريتمهاى تجميعى }
\end{aligned}
$$

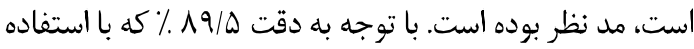

$$
\begin{aligned}
& \text { از اين روش در حل مسأله تشخيص جنسيت بهدست آمده } \\
& \text { است، مىتوان نتيجه گرفت كه تفاوتهاى جنسيتى در } \\
& \text { نوشتهای فضاى مجازى بلاكَها نيز وجود دارند. از طرفى با بان }
\end{aligned}
$$

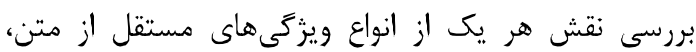

$$
\begin{aligned}
& \text { مشخص شد ويزگى هاى وازگكان گرامرى بيشترين تأثير در } \\
& \text { تفكيك نمونهها را داشته و يس از آن ويزكى هاى فاكتور وازثه } \\
& \text { در دستهبندى مؤثر بودهاند. همجنين بهدليل وجود غلط } \\
& \text { املايى و استفاده از وازگًان اختصارى غير رسمى در متون } \\
& \text { فضاى مجازى، ويثزى هاى وابسته به متن، بلطور خاص } \\
& \text { 5َnمى حروف با طول يك تا جهار، استخراج شدند، و نشان } \\
& \text { داده شد اين نوع ويزگىى، در دستهبندى جنسيت متن بلاكَها، } \\
& \text { و افزايش دقت دستهبندى تأثير بهسزايى دارد. }
\end{aligned}
$$

\section{7- References مراجع -V}

[1] N. Cheng, R. Chandramouli, and K.P. Subbalakshmi, "Author gender identification from text," Elsevier. Digital investigation, vol. 8, pp. 78-88, 2011.

[2] Z. Miller, B. Dickinson, and W. Hu, "Gender Prediction on Twitter Using Stream Algorithms with N-Gram Character Fcatures," International Journal of Intelligence Science, 2012.

[3] K. Mita, A. Mukesh, "Automatic Classification of Unstructured Blog Text," Journal of Intelligent Learning Systems and Applications, vol. 5, pp. 108-114, 2013.

[4] S. Argamon, M. Koppel, J. Fine, and A. Shimoni, "Gender, Genre and Writing Style in Formal Written Texts," Dept of Computer Science. Illinois Institute of Technology, pp. 321-346, 2003.

[5] G. Murugaboopathy, S. Hariharasitaraman, and N. Sankarram, "Appropriate Gender Identification from the Text," International Journal of Emerging Research in Management \&Technology, 2013. 


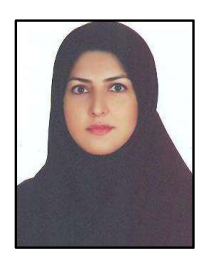

مهناز تسليمى درجه كارشناسى ارشد خود را در رشته مهندسى كامييوتر در سال F كرده و زمينههاى يزوهشى ايشان عبارت يادكيرى ماشين و دادهكاوى است است ائتان

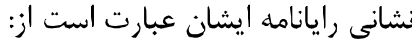
mahnaz_taslimi@yahoo.com

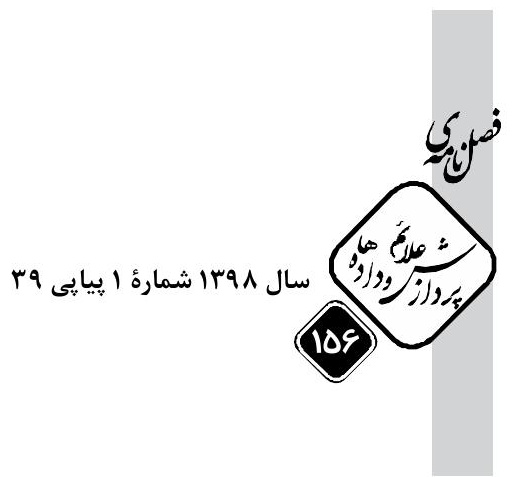

